Działo J., Are fiscal rules an effective instrument in consolidating public finances? Conclusions from the economic crisis, „Ekonomia i Prawo. Economics and Law”, Polszakiewicz B., Boehlke J. (ed.), Vol. 15, No. 1/2016, pp. 59-71. DOI: http://dx.doi.org/10.12775/EiP.2016.005.

\title{
ARE FISCAL RULES AN EFFECTIVE INSTRUMENT IN CONSOLIDATING PUBLIC FINANCES? CONCLUSIONS FROM THE ECONOMIC CRISIS
}

\author{
SUMMARY
}

The paper aims to assess the role of fiscal rules in the process of consolidating public finances and maintaining macroeconomic stability in the EU Member States in the period of the economic crisis. The paper puts forward the thesis that fiscal rules were not an effective instrument for ensuring fiscal discipline in times of crisis. It will present the most important issues of the process of evolution of the rules during the crisis. A review and an analysis of legislation and literature on reforms implemented in the area of fiscal rules, confirms this thesis. The paper points to the need to create such fiscal rules that could contribute not only to fiscal stability but also to macroeconomic stability of the economy and concludes with recommendations for the creation of effective fiscal rules and their desirable features. The rules should be based on the structural balance or the over the cycle balance (but, in order for such rules to be effective, the structural deficit should be relatively low). Effective enforcement of the rules is necessary as well as a strong legal basis for the rules. However, one may remember that the efficiency of the rules is also determined by causes and the scope of fiscal problems in individual countries. The rules alone are not sufficient to overcome the strong systemic and structural burdens placed on economies. In such

Joanna Działo, University of Lodz, Faculty of Economics and Sociology, Department of Economic Mechanisms, ul. Rewolucji 1905 r 41, 90-214 Lodz, Poland, +48 4263555 15, e-mail: jdzialo@uni.lodz.pl.

$\checkmark$ The article was funded by University of Lodz, Department of Economic Mechanisms. 
a situation, a better solution is to develop a long-term strategy for reducing deficit and debt levels, incorporating fiscal rules as one of its elements.

Keywords: effective fiscal rules; public finances; economic crisis; structural deficit; over the cycle deficit

JEL Classification: H30; H39; H62; H63

\section{INTRODUCTION}

One of the most important factors affecting the effectiveness of the fiscal policy conducted in the given country is the right choice of fiscal rules. The fulfillment of this condition is particularly important during an economic crisis, manifested, among others, in a drastic deterioration of the state of the public finance sector. As a result, the primary objective of fiscal rules in times of crisis is to reduce the budget deficit and public debt. It should be noted, however, that a failure to comply with the applicable fiscal rules (transnational and national) on the part of many Member States of the European Union was also a result of the economic crisis in public finances. It was a consequence of the economic slowdown/recession as well as the pursuit of particularistic interests by the EU countries. The fiscal policy became more discretionary, which resulted in a further deterioration of the condition of the public finance sector. As a result, the economic crisis revealed the need to reform the previously binding fiscal rules and the need to strengthen their enforceability in order to turn the rules into the instrument which, on the one hand, is a tool to ensure fiscal stability, and on the other, a tool which inhibits economic growth to the least degree.

The paper aims to assess whether the "pre-crisis" fiscal rules were an effective instrument in stabilising public finances in the EU countries. In addition, it will present the most important aspects of the process of evolution of the rules during the economic crisis and provide suggestions for the future direction of changes in the rules aimed at increasing their effectiveness in improving fiscal and macroeconomic stability.

\section{THE CURRENT STATE OF KNOWLEDGE AND THE METHODOLOGY OF RESEARCH}

In the aftermath of the financial crisis of 2007/2008 the EU faced a debt crisis, caused by high public deficits and uncertainty on the financial markets. As a consequence several initiatives have been brought forward to strengthen 
the EU's fiscal governance and regain trust into the sustainability of public finances. Fiscal rules, as part of this strengthened fiscal governance frameworks, have been one of the most important components of the EU's response to the sovereign debt crisis. As more and more data on national fiscal rules has become available, many studies have been published, which analyse the process of evolution of fiscal rules during the crisis as well as the general impact of the existence of fiscal rules on fiscal policy variables, like budget balance or debt levels. Most of these studies analysing the effect of fiscal rules on fiscal policy find a positive effect, i.e. more or stricter fiscal rules improve the public balances.

The paper uses the method of analysis of both the EU documents and literature. To achieve the goal formulated in the article, the comprehensive and critical literature studies and an analysis of legal sources was conducted. The method of descriptive and comparative analysis was implemented, and the author inferences and concludes on the basis of this analysis.

\section{THE ROLE OF FISCAL RULES IN CONDUCTING A SOUND FISCAL POLICY}

Conducting a sound fiscal policy is an important prerequisite to ensure the stability of the economy in the short as well as long term. A prudent fiscal policy, on the one hand, has a positive effect on economic growth and, on the other hand, in the long term, promotes the growth of confidence of the financial markets and contributes to maintaining relatively low interest rates ${ }^{1}$. This translates into higher economic growth and, consequently, contributes to an increase in budget revenues, which in turn results in improving the condition of public finances ${ }^{2}$.

Fiscal rules, understood as a quantitative restriction on the deficit level, public debt, government revenue or expenditure, usually stipulated in the Constitution or the relevant law, are one of the factors favouring the sound fiscal policy ${ }^{3}$. Fiscal rules may be introduced for several reasons.

${ }^{1}$ Communication from the Commission to the European Parliament, the European Council, the Council, the European Central Bank, the European Economic and Social Committee and the Committee of the Regions of 12 May 2010 - Reinforcing economic policy coordination, $\operatorname{COM}(2010) 250$, p. 21.

${ }^{2}$ European Central Bank, Fiscal policy influences on macroeconomic stability and prices, ECB Monthly Bulletin, April 2004, p. 14.

3 A. Schick, Post-Crisis Fiscal Rules: Stabilising Public Finance while Responding to Economic Aftershocks, "OECD Journal on Budgeting", Vol. 10, No. 2/2010, pp. 24-35. 
One of the reasons is to ensure macroeconomic stability in the economy and maintain a stable fiscal policy in the long term. The rules are also aimed at reducing negative externalities of pursuing an independent fiscal policy by the countries belonging to a specified federation of states (e.g.: the European Union countries). However, during an economic crisis, the primary objective of fiscal rules is to reduce excessive deficit and debt levels as well as to improve the credibility of the fiscal policy conducted.

\subsection{TYPES OF FISCAL RULES}

Fiscal rules usually comprise four groups:

- deficit rules,

- public debt rules,

- revenue rules,

- expenditure rules ${ }^{4}$.

Deficit rules are deficit limits which cannot be exceeded in a given budget year. They frequently take the form of a stipulation that over a given period of time (within the fiscal period) the budget deficit should not exceed a certain fixed threshold expressed as a percentage of GDP. Public debt rules consist in the imposition of limits on the total level of public debt in the form of debt-to-GDP ratio. Expenditure rules usually relate to aggregate expenditure.

The most popular spending limits are expenditure growth rules, according to which budget expenditure should grow at a certain rate, regardless of changes occurring on the revenue side of the budget. Revenue rules apply to budget income (revenue). Most often they are aimed at maintaining stable taxes and reducing rapid changes in their amounts. In addition, their goal may also be to establish rules for the allocation of surplus revenues, primarily in order to repay debt.

\section{2. "PRE-CRISIS" FISCAL RULES IN THE EUROPEAN UNION}

In order to join the Economic and Monetary Union, the EU Member States were required to fulfil the fiscal criteria laid down in the Protocol on the Excessive Deficit Procedure, which is an annex to the Maastricht Treaty, signed in 1992. The first criterion assumed that the budget deficit should not exceed 3\% of GDP. There were a few exceptions to the rule, e.g.: if the high

${ }^{4}$ C. Wyplosz, Fiscal Rules: Theoretical Issues and Historical Experiences, NBER Working Paper, No. $17884 / 2012$. 
deficit was being reduced in a permanent manner and was clearly approaching the set limit. The limit could also be exceeded if it was caused by a severe economic recession. The second criterion referred to the level of public debt and indicated that the level of debt in relation to GDP should not exceed $60 \%$. Also in this case, there could be exceptions as long as the pace of debt reduction was strong. The fiscal rules laid down in the Treaty of Maastricht proved to be quite effective and caused a visible decline in the deficit and debt levels in many EU countries. In 1993, the average deficit in the euro area candidate countries amounted to 5.5\% of GDP, while in 1997 it amounted to only $2 \%$ of GDP. In 1999, all the countries met the required criteria. However, since the entry into force of the European Monetary Union (2000), the Member States which joined the euro area have no longer adhered to the convergence criteria and have clearly loosened their fiscal policies ${ }^{5}$.

As over time the rules laid down in the Treaty of Maastricht came to be seen as not sufficiently precise, new fiscal rules enshrined in the Stability and Growth Pact (SGP) were adopted in 1997. The Pact upheld the fiscal rules introduced by the Treaty of Maastricht and in addition also required each of the countries with the common currency to achieve a budgetary position of close to balance or in surplus in the medium term (during a complete business cycle) - the so called Medium-Term Budgetary Objective (MTO). The Pact also clarified the exceptions relating to the determination of deficit as excessive, as well as detailed the two stages of the excessive deficit procedure: preventive and repressive. Moreover, it introduced the possibility of imposing fines for maintaining the deficit at excessive levels. The penalty took the form of a non-interest bearing deposit which was forfeited if within two years the excessive deficit was not reduced.

The SGP proved to be not a very effective mechanism to enforce a sound fiscal policy in the EU Member States. Undoubtedly, it was mostly due to the fact that a relatively great deal of freedom for discretionary decisions was left. For example, the European Commission could decide not to initiate disciplinary procedures if it determined that the exceeded limits were due to the occurrence of a temporary, exceptional emergency situation. Similarly, the use of fines did not occur automatically, but was decided by a qualified majority of the European Council, which highly politicised the decisions taken ${ }^{6}$.

${ }^{5}$ J. Działo, Polityczne uwarunkowania jakości instytucji fiskalnych, Wydawnictwo Uniwersytetu Łódzkiego, Łódź 2009, p. 116.

${ }^{6}$ A. Alesina, F. Giavazzi, Pakt Stabilizacji, który destabilizuje Europę, Rzeczpospolita, 02.11.2002. 
The evident economic slowdown, which occurred in 2001-2002, showed weaknesses of the SGP in disciplining the EU countries to pursue a sound fiscal policy. The SGP began to be assessed as too rigorous and preventing the adjustment of the fiscal policy to the changing economic situation. As a result, in 2004, the first reform of the Pact was carried out, consisting in introducing more flexible rules for its interpretation and application in the event of an excessive deficit (above 3\% of GDP). The reform introduced mitigating factors that the European Commission should consider initiating the excessive deficit procedure, as well as the possibility of extending the transitional period for the elimination of the excessive deficit. As a result, the reform caused the weakening of the repressive arm of the Pact and it did not strengthen the preventive part, which can be considered as a step towards "easing" of its provisions and facilitating non-compliance ${ }^{7}$.

Assessing the effectiveness of the pre-crisis fiscal rules in disciplining the fiscal policy, it should be noted that the greatest difficulty was associated with ensuring compliance. The mechanism of sanctions contained in the SGP proved to be ineffective and the decision of the European Council of November 2003 not to take sanctions against France and Germany within the framework of the excessive deficit procedure was the most obvious example. The decision was perceived as a blatant example of dependency of the provisions of the SGP on political factors ${ }^{8}$. It should also be noted that after the introduction of the rules, a significant reduction in the flexibility of the fiscal policy in response to the changing reality occurs. In addition, wrongly chosen solutions can have a procyclical effect, contributing to a further weakening of the economy and the deterioration of public finances 9

The so-called illusory effectiveness of fiscal rules is also an important problem. Quasi-fiscal operations and creative accounting, when fiscal authorities manipulate fiscal data to demonstrate that fiscal rules have not been breached, can serve as examples. The most common are operations carried out using public funds outside the budget, which makes the official budget deficit lower than the actual one. Another example is the transfer of debt between the various elements of the public finance sector. For example, if strict borrowing rules apply only to the government (the central level), it raises

${ }^{7}$ L. Oręziak, Finanse Unii Europejskiej, PWN, Warszawa 2009, p. 48.

${ }^{8}$ T. Jędrzejowicz, M. Kitala, A. Wronka, Polityka fiskalna w kraju należacym do strefy euro. Wnioski dla Polski, [in:] NBP, Raport na temat petnego uczestnictwa Rzeczypospolitej Polskiej w trzecim etapie Unii Gospodarczej i Walutowej. Warszawa 2009, pp. 39-58.

${ }_{9}$ K. Wójtowicz, Problem konstrukcji optymalnej reguty fiskalnej w warunkach kryzysu finansowego, "Zeszyty Naukowe PTE”, No. 10/2011, pp. 137-152. 
a temptation to transfer the debt to the local government sector ${ }^{10}$. Creative accounting is relatively easy when public finances are not very transparent. As a result, countries conducting a sound fiscal policy seek to pursue it regardless of the applicable fiscal rules, whereas the states which tend to generate excessive deficits relatively easy circumvent fiscal rules ${ }^{11}$.

\subsection{FISCAL RULES DURING THE ECONOMIC CRISIS}

One of the effects of the economic crisis was a rapid deterioration of public finances in most EU Member States. A severe recession and a significant rise in unemployment led to the need to increase the scope of the discretionary policy and to provide financial support for economies from national budgets, which in turn dramatically increased budget deficits and public debts in many EU countries. As a result, many EU Member States were no longer able to fulfil the applicable fiscal rules, both the EU (supranational) and national ones. Therefore, the EU began to seek new solutions to improve fiscal discipline, carrying out reforms of supranational fiscal rules. On the other hand, many Member States applying national rules eased the criteria (often for a limited time) of compliance with the rules or introduced new rules.

In 2010, actions were taken to carry out further reforms of the SGP in order to adapt it better to the existing economic realities. As a result, there has been an increase in the importance of the public debt criterion which while unfulfiled may cause the imposition of the excessive deficit procedure. Due to the new solutions, the EU can take actions when the budget deficit does not exceed 3\% of GDP, but the public debt is above 60\% of GDP. Other significant changes include the strengthening of the system of incentives and sanctions by introducing an obligation for Member States to provide interest-bearing deposits in the case of conducting an irresponsible fiscal policy, as well as by introducing the possibility of suspending funding from the EU Cohesion Fund. In addition, the so-called "European Semester" was established, whereby the Member States may seek the EU's assessment of their national budgetary plans and national reform programmes in the course of their preparation $^{12}$.

Successive reforms were carried out in 2011 (the so-called six-pack), in response to the fiscal crisis in Greece, Ireland and Portugal, which began to threaten the large economies (Italy and Spain) as well. It turned out that

\footnotetext{
${ }^{10}$ K. Marchewka-Bartkowiak, Reguły fiskalne, “Analizy BAS”, No. 7(32)/2010, pp. 32-41.

${ }^{11}$ J. Giżyński, Polityka fiskalna w strefie euro, CeDeWu, Warszawa 2013, p. 68.

12 Communication from the Commission..., op. cit.
} 
the previously existing system did not have mechanisms to encourage the reduction of public debt. The principle of "a satisfactory pace of debt reduction" was then introduced for countries exceeding $60 \%$ of GDP, according to which within three years the distance to the reference value was to decrease at the rate of one twentieth per year. In the case of failure, the country is to be subject to the excessive deficit procedure and given time to take corrective actions. Non-compliance may result in financial sanctions. Countries belonging to the euro area will be additionally required to pay a deposit amounting to 0.2 percent of GDP. If a given country fails to regain financial stability, it will lose the deposit in the framework of the imposed sanctions ${ }^{13}$. The preventive part of the SGP was also modified through the use of the new expenditure rule whose purpose was to discipline the EU countries to implement the MTO. According to the rule, the annual increase in budgetary expenditure in the EU Member State should not exceed the medium-term rate of growth of the country's potential $\mathrm{GDP}^{14}$. The changes introduced were to potentially to improve fiscal discipline, although the problem of enforceability of the adopted provisions was still not eliminated. The principle of automaticity was not applied and the relationship between the European Commission and the European Council was not changed. The European Commission remained the applicant institution and the European Council made decisions by a simple majority, which created a relatively high chance of rejection of sanctions.

The next step on the path of reforms was the signing of the Fiscal Compact on 2 March 2012. The most important provisions of the Compact include the new golden rule of the budget balance according to which the structural budget deficit cannot exceed $0.5 \%$ of the country's nominal $\mathrm{GDP}^{15}$. The strengthening of the EU's control over Member States' fiscal discipline by including in the national law of the EU countries obligatory implementation of the MTO is considered a very significant and innovative solution. Enforceability of the proposed solutions has also been strengthened as the EC's consent is no longer necessary to initiate the excessive deficit procedure and sanctions are applied automatically when the rules are violated ${ }^{16}$.

${ }^{13}$ J. Działo, Czy Unia Europejska potrzebuje unii fiskalnej?, [in:] J. Sokołowski, A. Żabiński, Finanse publiczne, "Prace Naukowe UE we Wrocławiu", Wrocław 2013, pp. 86-97.

${ }_{14}$ J. Giżyński, op. cit., p. 74.

15 Treaty on Stability, Coordination and Governance in the Economic and Monetary Union, http:/www.consilium.europa.eu/en/european-council/pdf/Treaty-on-Stability-Coordinationand-Governance-TSCG (15.07.2015).

${ }^{16}$ E. Kaliszuk, Kontrowersyjny traktat fiskalny, “Unia Europejska.pl”, No. 2(213)/2012, p. 9. 
Two additional mechanisms intended only for the euro area countries, the so-called two-pack, adopted on 30 May 2013, should also be mentioned. The first regulation lays down specific rules with regard to countries covered by the excessive deficit procedure. The second regulation lays down rules for enhanced surveillance in countries experiencing serious difficulties with maintaining financial stability and those that receive financial assistance ${ }^{17}$.

\section{FEATURES OF AN EFFECTIVE FISCAL RULE. POST-CRISIS REFLECTIONS}

As mentioned earlier, fiscal rules during the economic slowdown of 20012002, and especially in times of the subsequent economic crisis, proved to be ineffective. The rule mechanism did not prevent excessive deficits or debt build-up in most EU countries. The basic underlying reason for the said situation was related to the fact that during the crisis many countries failed to rely solely on automatic stabilisers of the economic cycle and started to implement discretionary fiscal policies. The high budgetary expenditure and/or reduction of the tax burden in order to stimulate the economy resulted in the need for breaches of fiscal rules and deepened the imbalance of public finances. Most EU Member States sacrificed their fiscal stability for the sake of restoring their macroeconomic balance. Unfortunately, such actions resulted in a further increase of deficit and debt levels and thus forced a search for solutions to promote both fiscal and economic balance.

The economic crisis has shown that the EU has not developed fiscal rules that would satisfy the above-mentioned criterion. Both deficit rules and debt rules laid down in the Maastricht Treaty act pro-cyclically, as rigid limits on deficit/debt do not facilitate conducting a prudent fiscal policy in times of prosperity, while forcing fiscal retrenchment during a slowdown/recession. Fiscal rules based on cyclically adjusted balance (the structural balance) offer the possibility to mitigate cyclical fluctuations since they eliminate the impact of automatic stabilisers, allowing the implementation of a flexible fiscal poli$\mathrm{cy}^{18}$. However, the main problem with fulfiling such a rule is too high structural deficits in most EU countries. In order for the fiscal policy to stabilise the economic situation (not to be pro-cyclical), the structural deficit should be kept as low as possible. Then, even in times of recession, when there is the cy-

17 European Commision, http://www.europa.eu (17.07.2015).

${ }_{18}$ International Monetary Fund, Fiscal Rules - Anchoring Expectations for Sustainable Public Finances, 2009, p. 27. 
clical deficit, the actual (cyclical and structural) deficit has a good chance not to exceed the threshold of $3 \%$ of GDP. This means that with the low structural deficit, the actual deficit is mainly determined by the level of the cyclical deficit. If this condition is fulfiled, fiscal stability and macroeconomic stability are ensured primarily through the operation of automatic stabilisers of the economic cycle. The impact of the stabilisers would provide funding of the structural deficit with the cyclical surplus which would accrue in times of economic prosperity ${ }^{19}$.

The problem is, however, that the mechanism fails when the structural deficit is excessive. In periods of recession, a high structural deficit would force conducting a restrictive fiscal policy so that the actual deficit should not exceed a designated threshold. As a result, the fiscal policy instead of being countercyclical, would become procyclical. The data contained in table 1 show that the structural deficit of the EU Member States for many years had remained at a relatively high level, which resulted in a high actual deficit, especially during the economic crisis. In conclusion, in order to ensure fiscal and macroeconomic stability, the structural deficit should be low for the entire duration of the economic cycle. In this case, the structural balance rule will have the desirable features, i.e. it will serve to stabilise public finances as well as the economy.

Table 1. The structural deficit of the EU countries belonging to the Economic and Monetary Union (\% GDP)

\begin{tabular}{|c|c|c|c|c|c|c|c|c|c|c|c|}
\hline 2000 & 2001 & 2002 & 2003 & 2004 & 2005 & 2006 & 2007 & 2008 & 2009 & 2010 & 2011 \\
\hline 1.35 & 2.75 & 2.97 & 2.94 & 2.98 & 2.45 & 1.90 & 1.95 & 2.65 & 4.45 & 4.56 & 3.20 \\
\hline
\end{tabular}

Source: European Commission, Public finances in EMU 2010, Luxembourg 2010.

However, the structural balance of the budget is also not an optimal solution as it is not safe from the impact of discretionary actions taken by the state to stabilise its economy. Therefore, a better solution is to extend the time horizon of the rules on the budget balance for the entire cycle. Then the adopted limits refer to the average level of the nominal over the cycle budget balance ${ }^{20}$. Thus constructed rules are much more flexible as the effects

19 L. Próchnicki, Reguty fiskalne jako narzędzie utrzymania stabilności fiskalnej w Krajach Unii Europejskiej, "Studia Zarządzania i Finansów", Wyższa Szkoła Bankowa w Poznaniu, No. 3/2012, pp. 27-51.

${ }^{20}$ K. Wójtowicz, op. cit., pp. 137-152. 
of expansionary discretionary measures taken during the economic crisis are offset by a corresponding tightening of the policy in the expansion phase ${ }^{21}$.

The above-mentioned rules of the structural balance and over the cycle balance can be completed with the public debt rule. However, in terms of its countercyclical impact, this rule is subject to similar conditions as the budget balance rules. Expenditure rules stabilise public debt when they are expressed as limits of the share of total public expenditure in GDP or designate a maximum growth rate of spending in relation to GDP growth over a certain period of time. However, in terms of their countercyclical impact, the rules are particularly ineffective as they limit the operation of automatic stabilisers and discretionary instruments used in the recession phase to stimulate the economy ${ }^{22}$.

Flexibility of fiscal rules can also be increased by writing precisely the socalled exit clauses, i.e. conditions that allow the unfulfilment of the rule. These exceptions should be clearly defined and should indicate the time and the path back to the fulfilment of the rule. This solution limits the discretion, and at the same time is conducive to macroeconomic stability.

It is also important to ensure compliance with the rules. Therefore, it is so vital for fiscal rules to have strong legal foundations, i.e. to be enshrined in the Constitution or a relevant Act. The incorporation of the rules in the legal system is a tool strongly limiting the freedom of politicians in shaping the fiscal policy.

And finally, the effectiveness of the enforcement of fiscal rules could be increased if the application of the rules was supervised by an independent government institution (e.g.: the Fiscal Policy Council). This institution would conduct monitoring of the current fiscal policy, control the deficit and debt, and if necessary would recommend taking corrective actions. Such Councils already operate in many countries and their activity is assessed positively.

\section{CONCLUSIONS}

The appropriate construction of fiscal rules and an effective mechanism to force compliance are essential to ensure the effectiveness of fiscal rules. Effective fiscal rules ought to combine the two following criteria: they should stabilise public finances and should not inhibit economic growth. The simul-

${ }^{21}$ F. Balassone, M.S. Kumar, Cyclicality of Fiscal Policy, [in:] M.S. Kumar, T. Ter-Minassian (eds.), Promoting Fiscal Discipline, IMF, 2007, pp. 34-58.

${ }^{22}$ European Commission, Public finances in EMU 2010, Luxembourg 2010, p. 23. 
taneous fulfilment of these two conditions, seemingly contradictory, is possible with the use of rules based on the structural balance or the over the cycle balance. However, in order for such a rule to be effective, the structural deficit should be relatively low. In most of the EU Member States, it is, however, at a high level. Reducing the structural deficit (which is stipulated by the Fiscal Pact) means a reduction of rigid expenditure, which is very difficult in countries with a high level of debt as debt servicing itself consumes sometimes more than $2 \%$ of GDP. This means that spending cuts must also involve social expenditure and result in a reduction of the so-called welfare state.

Effective enforcement of the rules is possible by means of universality and inevitability of sanctions, as well as by ensuring the speed of their activation and the use of a control mechanism, e.g.: in the form of an independent Fiscal Policy Council. In addition, a strong legal basis for the rules is important, as well as limiting the use of creative accounting and extra-budgetary operations.

The effectiveness of the rules is also determined by causes and the scope of fiscal problems in individual countries. The rules alone will not suffice where there are strong systemic and structural burdens placed on economies as they will be circumvented or openly ignored. In such a situation, the development of a long-term strategy for reducing deficit and debt levels, incorporating fiscal rules as one of its elements, is a better solution.

\section{BIBLIOGRAPHY}

Alesina A., Giavazzi F., Pakt Stabilizacji, który destabilizuje Europe, "Rzeczpospolita", 02.11.2002.

Balassone F., Kumar M.S., Cyclicality of Fiscal Policy, [in:] M.S. Kumar, T. Ter-Minassian (eds.), Promoting Fiscal Discipline, IMF, 2007.

Communication from the Commission to the European Parliament, the European Council, the Council, the European Central Bank, the European Economic and Social Committee and the Committee of the Regions of 12 May 2010 - Reinforcing economic policy coordination, $\operatorname{COM}(2010) 250$.

Działo J., Czy Unia Europejska potrzebuje unii fiskalnej?, [in:] J. Sokołowski, A. Żabiński, Finanse publiczne, "Prace Naukowe UE we Wrocławiu", Wrocław 2013.

Działo J., Polityczne uwarunkowania jakości instytucji fiskalnych, Wydawnictwo Uniwersytetu Łódzkiego, Łódź 2009.

European Central Bank, Fiscal policy influences on macroeconomic stability and prices, ECB Monthly Bulletin, April 2004.

European Commision, http://www.europa.eu (17.07.2015).

European Commission, Public finances in EMU 2010, Luxembourg 2010. 
Giżyński J., Polityka fiskalna w strefie euro, CeDeWu, Warszawa 2013.

International Monetary Fund, Fiscal Rules - Anchoring Expectations for Sustainable Public Finances, 2009.

Jędrzejowicz T., Kitala M., Wronka A., Polityka fiskalna w kraju należacym do strefy euro. Wnioski dla Polski, [in:] NBP, Raport na temat petnego uczestnictwa Rzeczypospolitej Polskiej w trzecim etapie Unii Gospodarczej i Walutowej. Warszawa 2009.

Kaliszuk E., Kontrowersyjny traktat fiskalny, "Unia Europejska.pl”, No. 2(213)/2012.

Marchewka-Bartkowiak K., Reguty fiskalne, "Analizy BAS”, No. 7(32)/2010.

Oręziak L, Finanse Unii Europejskiej, PWN, Warszawa 2009.

Próchnicki L., Reguty fiskalne jako narzędzie utrzymania stabilności fiskalnej w Krajach Unii Europejskiej, "Studia Zarządzania i Finansów", Wyższa Szkoła Bankowa w Poznaniu, No. 3/2012.

Schick A., Post-Crisis Fiscal Rules: Stabilising Public Finance while Responding to Economic Aftershocks, "OECD Journal on Budgeting", Vol. 10, No. 2/2010, http:// dx.doi.org/10.1787/budget-10-5km7rqpkqts1.

Treaty on Stability, Coordination and Governance in the Economic and Monetary Union, http://www.consilium.europa.eu/en/european-council/pdf/Treaty-on-Stability-Coordination-and-Governance-TSCG (15.07.2015).

Wójtowicz K., Problem konstrukcji optymalnej reguty fiskalnej w warunkach kryzysu fnansorvego, "Zeszyty Naukowe PTE”, No. 10/2011.

Wyplosz C., Fiscal Rules: Theoretical Issues and Historical Experiences, NBER Working Paper, No. 17884/2012, http://dx.doi.org/10.3386/w17884. 
